\title{
Simple Mechanical Beneficiation Method of Coarse Fly Ash with High LOI for Making HVFA Mortar
}

\author{
Antoni $^{1^{*}}$, Satrya, V. ${ }^{2}$, and Hardjito, D. ${ }^{1}$
}

\begin{abstract}
This study focusses on the effect of milling of fly ash obtained from four different sources on the properties of high volume fly ash (HVFA) mortar. Two fly ash samples with low loss-on-ignition (LOI) were taken from a coal-fired power plant, while the other two with high LOIs were obtained from a textile factory and from a paper mill, respectively. Milling was performed using a rod mill at a certain period of time. The workability of HVFA mortar with constant water to cementitious ratio was controlled by adjusting the superplasticizer content. The results show that the specific gravity of fly ash increases after milling. Utilizing milled fly ash ends up with significant strength increase of HVFA mortar, especially those utilizing high LOI fly ash. This shows that milling is an excellent fly ash beneficiation technique, especially on the one with high LOI value.
\end{abstract}

Keywords: Fly ash; HVFA; high LOI; mechanical beneficiation; milling.

\section{Introduction}

Fly ash utilization as partial replacement for cement in making concrete often hindered due to the presence of high amount of unburnt carbon, which is indicated by its high loss-on-ignition (LOI) content. ASTM C618 limits the carbon content not more than $6 \%$ to prevent discoloration, poor air entraintment and segregation of fresh concrete mixture [1].

Fly ash properties may vary significantly. It may depend on the type of industry and the process involved in generating this waste material. Power plants generally produce better quality fly ash with low LOI value, due to better control on the burning process, than other industries.

Good quality fly ash with low LOI is desirable by the ready mix industries. Its usage reduces the cost of concrete production, and at the same time it also results in good performance of concrete, such as more workable, higher strength, better durability, and lower shrinkage. However, there are large quantities of low quality fly ash with high LOI values available $[2,3]$. Without any proper treatment, due to its poor performance, this kind of fly ash is hardly used in concrete production,

\footnotetext{
${ }^{1}$ Department of Civil Engineering, Petra Christian University, J Siwalankerto 121-131, Surabaya 60236, INDONESIA

${ }^{2}$ Postgraduate Program in Civil Engineering, Petra Christian University, Jl. Siwalankerto 121-131, Surabaya 60236, INDONESIA

*Corresponding author; e-mail: antoni@petra.ac.id
}

Note: Discussion is expected before June, $1^{\text {st }} 2015$, and will be published in the "Civil Engineering Dimension" volume 17, number 2, September 2015.

Received 21 February 2015; revised 26 February 2015; accepted 27 February 2015. and ends up with the disposal of the fly ash to landfill. There has been a growing and persistent need to foster the development of efficient recycling method for coal fly ash [2].

Beneficiation of fly ash has been studied in recent years and several methods have been proposed to separate good quality cementitious material from the combustible one, such as separation [2,4], wet milling and acid leaching [5], thermal treatment in fluidized bed reactors [6], ultrasonic sieving and triboelectrostatic separation [1,7], grinding in eccentric vibratory mill $[8,9]$, and reburning [10]. However, most of the methods normally involve complex processes.

Mechanical activation of fly ash through a laboratoryscale-ball-milling has been proved to be efficient to improve the reactivity of fly ash as raw material for geopolymer cured under ambient temperature [11, 12]. To enable the wider application of the beneficiation method, especially on the coarse and high LOI fly ash, a simpler beneficiation method should be developed. This study aims to evaluate the mechanical activation of coarse and high LOI fly ash by grinding it using a simple rod mill, to improve its quality and to make it more desirable to be used as cementitious material, especially in producing high volume fly ash (HVFA) mortar.

\section{Materials and Experimental Program}

\section{Materials}

Four different fly ash samples were utilized for the experiment. Fly ash samples coded A and B were obtained from a coal-fired power plant in Paiton, East Java, Indonesia, taken at different time and from different units. Fly ash from this power plant is 
well known for its good quality, and is widely used by local ready mix industries. The other two fly ash samples were obtained from a textile factory $(\mathrm{C})$ and from a paper mill (D), both located in East Java, Indonesia. Fly ash $\mathrm{A}$ and $\mathrm{B}$ have brown and light brown color, while fly ash $\mathrm{C}$ and $\mathrm{D}$ show greyblackish color (Figure 1).
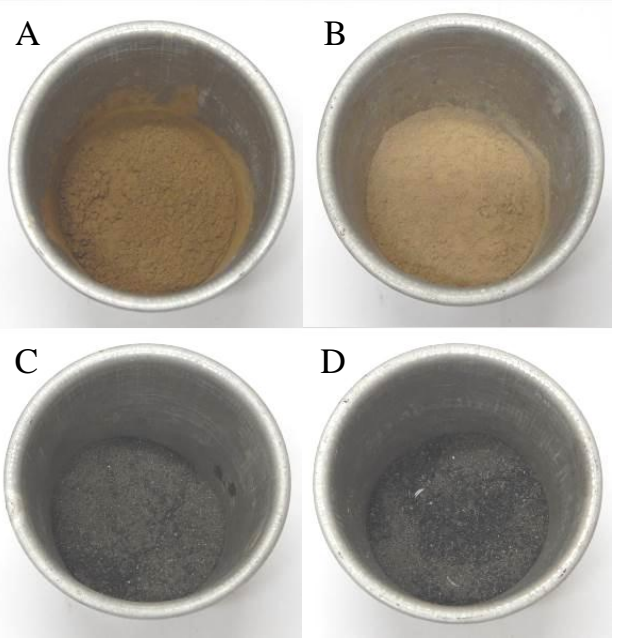

Figure 1. Four Different Fly Ash Samples

Chemical composition of fly ash was determined by X-ray Fluorescence (XRF) analysis and the results are presented in Table 1 . The LOI values of the fly ash show that the quality of the fly ash varies and can be categorized into two types, i.e. the ones with low LOIs (fly ash A and B) and the ones with high LOIs (fly ash C and D). ASTM C618 sets the maximum limit of LOI of not more than $6 \%$ for fly ash to be used as cementitious material. High LOI content reflects the high amount of unburnt carbon content in the fly ash, which plays important role in the adsorption capacity of the material [13]. Fly ash $\mathrm{B}$ also possesses high $\mathrm{CaO}$ content of more than $10 \%$, by mass, and thus can be considered as type $\mathrm{C}$ fly ash [14].

\section{Mechanical Activation}

To perform the mechanical activation of the fly ash, a simple rod mill has been constructed. It consists of a steel drum, $600 \mathrm{~mm}$ in diameter and $900 \mathrm{~mm}$ in length, and filled with with $80 \mathrm{~kg}$ of $12 \mathrm{~mm}$ diameter and $800 \mathrm{~mm}$ long steel rods. The drum is rotated about 40 rotation-per-minute. The optimum grinding capacity of the rod mill is between $15-20 \mathrm{~kg}$ (see Figure 2).

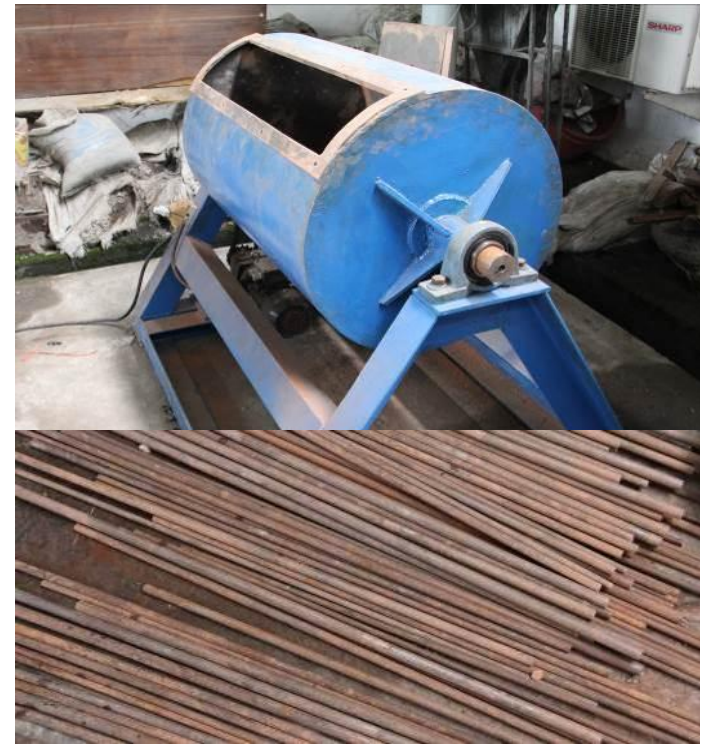

Figure 2. Rod Mill and Steel Rods for Grinding the Fly Ash

From the previous study [15], it was apparent that grinding cementitious materials, in this case calcined Sidoarjo volcanic mud, using this simple equipment increases its reactivity by increasing the specific surface area (SSA) and reducing the particle size of the powder material. With calcined Sidoarjo volcanic mud, it was found that eight hours milling time was the most optimum milling time, and thus the same period of milling time was chosen for this experiment.

Table 2 shows the change of particle size and the specific surface area (SSA) of fly ash due to milling. Milling time 0 hour indicates the original properties of the fly ash before milling, while milling time 8hour shows the properties of the fly ash after 8 hours milling. It is shown that fly ash A and B are already very fine in its original condition, compared to fly ash $\mathrm{C}$ and D. Most of the particles of fly ash A and B are less than $40 \mu \mathrm{m}$ in size. On the other hand, more than $50 \%$ of particles of fly ash C and D, by mass, are bigger than $40 \mu \mathrm{m}$. Milling or grinding for eight hours significantly reduced the particle size of fly ash C and D, as it can be seen from the values of D90. D90 denotes the size whereby $90 \%$ of the particles, by mass, are smaller than that. However, for the fine fly ash $\mathrm{A}$ and $\mathrm{B}$, the change is not as significant as in the case of the coarse ones. The same tendencies can be seen from the change in the values of specific

Table 1. Chemical Composition of Fly Ash as Measured by XRF (\% by mass)

\begin{tabular}{crrrrrrrrrrrr}
\hline Fly ash & $\mathrm{SiO}_{2}$ & $\mathrm{Al}_{2} \mathrm{O}_{3}$ & \multicolumn{1}{c}{$\mathrm{Fe}_{2} \mathrm{O}_{3}$} & $\mathrm{TiO}_{2}$ & \multicolumn{1}{c}{$\mathrm{CaO}$} & $\mathrm{MgO}$ & $\mathrm{Cr}_{2} \mathrm{O}_{3}$ & $\mathrm{~K}_{2} \mathrm{O}$ & $\mathrm{Na}_{2} \mathrm{O}$ & $\mathrm{SO}_{3}$ & $\mathrm{Mn}_{3} \mathrm{O}_{4}$ & $\mathrm{LOI}$ \\
\hline A & 42.56 & 26.76 & 9.67 & 1.14 & 6.59 & 3.54 & 0.01 & 1.26 & 0.88 & 7.04 & 0.11 & 0.33 \\
$\mathrm{~B}$ & 43.38 & 18.54 & 15.29 & 0.77 & 12.20 & 5.43 & 0.02 & 1.32 & 1.05 & 1.43 & 0.14 & 2.12 \\
$\mathrm{C}$ & 44.51 & 22.44 & 15.95 & 1.19 & 8.98 & 1.91 & 0.05 & 2.05 & 0.63 & 1.55 & 0.11 & 28.66 \\
$\mathrm{D}$ & 39.71 & 16.38 & 26.15 & 0.83 & 8.86 & 5.12 & 0.02 & 0.87 & 0.89 & 0.58 & 0.35 & 23.83 \\
\hline
\end{tabular}


Table 2. Milling Time and Change of Particle Size and SSA of Fly Ash

\begin{tabular}{cccrrrr}
\hline \multirow{2}{*}{ Fly Ash } & Milling Time (hour) & $\begin{array}{l}\text { D10 } \\
(\mu \mathrm{m})\end{array}$ & $\begin{array}{c}\text { D50 } \\
(\mu \mathrm{m})\end{array}$ & $\begin{array}{c}\text { D90 } \\
(\mu \mathrm{m})\end{array}$ & $\begin{array}{c}\text { D100 } \\
(\mu \mathrm{m})\end{array}$ & $\begin{array}{c}\text { SSA } \\
\left(\mathrm{m}^{2} / \mathrm{kg}\right)\end{array}$ \\
\hline \multirow{2}{*}{$\mathrm{A}$} & 0 & 1.79 & 9.15 & 39.78 & 142.53 & 1338 \\
& 8 & 1.77 & 9.96 & 34.84 & 97.87 & 1286 \\
B & 0 & 1.31 & 8.55 & 36.91 & 162.38 & 1538 \\
& 8 & 1.91 & 9.19 & 33.94 & 109.47 & 1324 \\
C & 0 & 8.66 & 46.76 & 152.89 & 660.35 & 462 \\
& 8 & 1.45 & 9.01 & 43.33 & 141.07 & 1506 \\
D & 0 & 8.06 & 42.50 & 168.00 & 664.00 & 521 \\
\end{tabular}

Table 3. Milling Time and Increase of Specific Gravity of Fly Ash

\begin{tabular}{ccccc}
\hline \multirow{2}{*}{ Fly Ash } & $\begin{array}{c}\text { Milling Time } \\
\text { (hour) }\end{array}$ & $\begin{array}{c}\text { LOI } \\
\text { (\% by mass) }\end{array}$ & $\begin{array}{c}\text { Specific Gravity } \\
\text { Increase of Specific } \\
\text { Gravity }\end{array}$ \\
\hline \multirow{2}{*}{ A } & 0 & 0.33 & 2.75 & 0.44 \\
& 8 & 0.01 & 3.19 & 0.12 \\
B & 0 & 2.12 & 2.06 & 0.18 \\
& 8 & 0.87 & 2.18 & 0.77 \\
\end{tabular}

surface areas (SSA). Apparently, the simple grinding equipment constructed is efficient to grind the coarse material only, it is not so for the fine materials with D90 less than than $40 \mu \mathrm{m}$. After eight hours milling time, the particle size, the particle size distribution and the specific surface (SSA) area of the four fly ash samples become similar one to the other.

Milling increases the values of the specific gravity of fly ash, although the change does not really show any regular pattern, as can be seen in Table 3 . Seemingly, it is due to the change in the particle packing condition to be more dense for the finer particles. On the other hand, the LOI values are slightly reduced after milling, although the values for fly ash $\mathrm{C}$ and $\mathrm{D}$ are still far above the $6 \%$ limit.

\section{Mixture Composition of HVFA Mortar}

For the mixture composition of the mortar specimens, both the water-to-cementitious ratio and sandto-cementitious ratio were set constant, at 0.2 and 2 by mass, respectively. In this regard, water content was also set constant, as the content of the cementitious materials was also constant. Cementitious materials consisted of the combination of Portland Pozzolan Cement (PPC) and fly ash. PPC is produced by a local cement manufacturer, and the only type available in the market for common use. The use of fly ash in the mixtures was set at $50 \%$ by mass, of the total cementitious material, when investigating the effect of milling on the reactivity of different type of fly ash. In evaluating the influence of fly ash usage or replacement ratio, the amount of fly ash was varied from 40 to $60 \%$, by mass, of the total cementitious material.
All the HVFA mortar mixtures were prepared based on a constant consistency condition. Polycarboxylatebased superplasticizer was added to the fresh mixture to obtain the flow diameter of $18 \pm 1 \mathrm{~cm}$ in mortar flow table test. The constant consistency target is important to ensure that the mortar properties are comparable in term of its compactibility and waterto-cementitious ratio.

High volume fly ash (HVFA) mortar specimens were casted in cubical shape mould of $5 \times 5 \times 5 \mathrm{~cm}^{3}$. Curing was performed by soaking the specimens in the fresh water until one day before the testing days at the age of 14 and 28 days. Each compressive strength data represents the average value of the results from testing three cubical specimens.

For the designation, C85 denotes the use of fly ash C with eight hours milling time and 50\% fly ash usage of the total cementitious materials, by mass. A06 indicates the use of fly ash $\mathrm{A}$ in its original form $(0$ milling time) and $60 \%$ usage of fly ash of the total cementitious materials, by mass.

\section{Results and Discussion}

\section{Consistency and Superplasticizer Demand}

The water content, water-to-cementitious ratio, and sand-to-cementitious ratio of all mortar mixtures were set constant. For the purpose of evaluating the superplasticiser demand when using four different types of fly ash to produce HVFA mortar, the amount of fly ash uitilized was set constant as well, at the level of $50 \%$ of the total cementitius materials, by mass. 


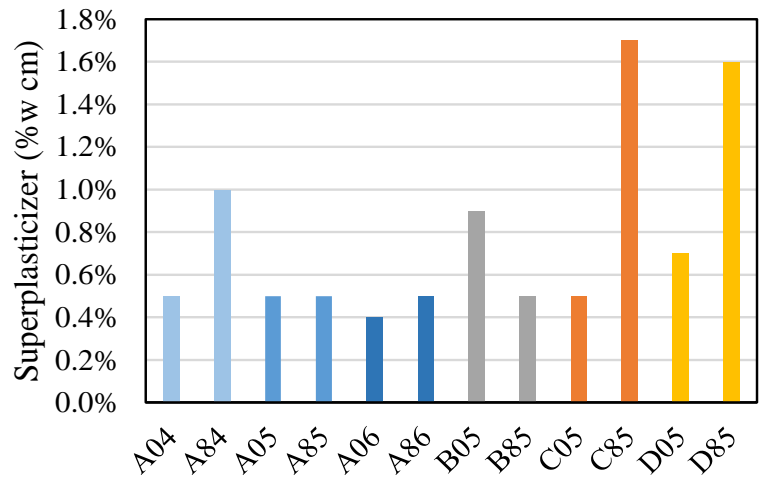

Figure 3. Superplasticizer Demand to Achieve Target Mortar Flow Diameter of $18 \pm 1 \mathrm{~cm}$

To achieve the similar target consistency for all mixtures, polycarboxylate-based superplasticizer was added, rather than altering the water content. Superplasticizer demand for the target consistency of flow diameter of $18 \pm 1 \mathrm{~cm}$, measured from flow table test, is shown in Figure 3.

All mortar mixtures utilizing original un-milled fly ash required $0.5-0.8 \%$ superplasticizer, by mass of the cementitious materials, to achive the target flow diameter. For those using the milled ones, in general, fresh mortar mixtures using fly ash A and B did not show any significant change in superplasticizer demand, with the exception of mixture A84, whereby the phenomenon is still un-clear. However, the ones utilizing milled fly ash $\mathrm{C}$ and $\mathrm{D}$ experienced a significant increase in superplasticizer demand of up to $1.5 \%$.

Most probably this was due to the high carbon content of fly ash C and D that absorbed part of the water and admixture, and lead to higher superplasticizer demand. Milling fly ash increases the number of fly ash particles, and hence also the number of the carbon particles. Milling fly ash also fractures the originally spherical fly ash particles to be particles with irregular shape and rough surface. It lowers the workability of the fresh mortar mix, and thus increases the need for superplasticizer.

Milling fly ash to reduce its particle size in order to increase its reactivity may affect the workability of mortar or concrete produced. This lack of workability of the fresh mortar or concrete mixtures may cause unexpected results, as the high reduction of strength may happen. This mostly due to difficulty in compaction rather than poor fly ash quality. In this regard, the use of superplasticizer should be considered to control the workability.

\section{Compressive Strength and Density}

Figures 4 and 5 show the 28-day compressive strength and density of HVFA mortar incorporating fly ash A, for both original and milled forms. The amount of fly ash incorporated was varied from 40 to $60 \%$.

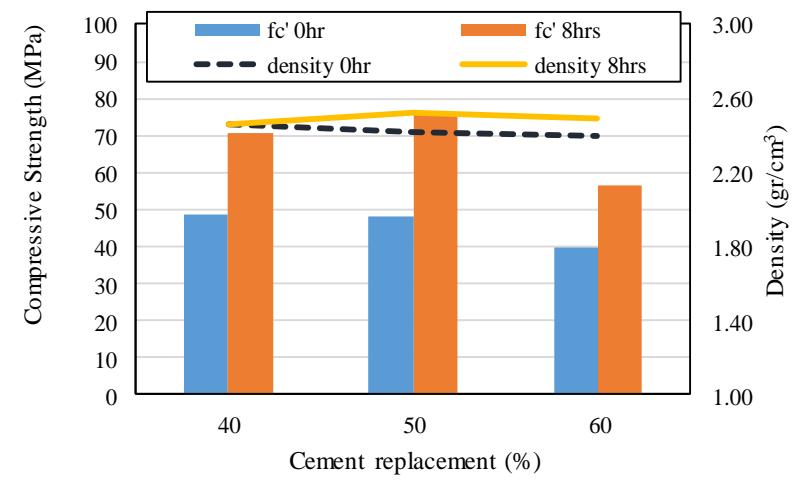

Figure 4. Compressive Strength and HVFA Mortar Density with Fly Ash A at 28 days

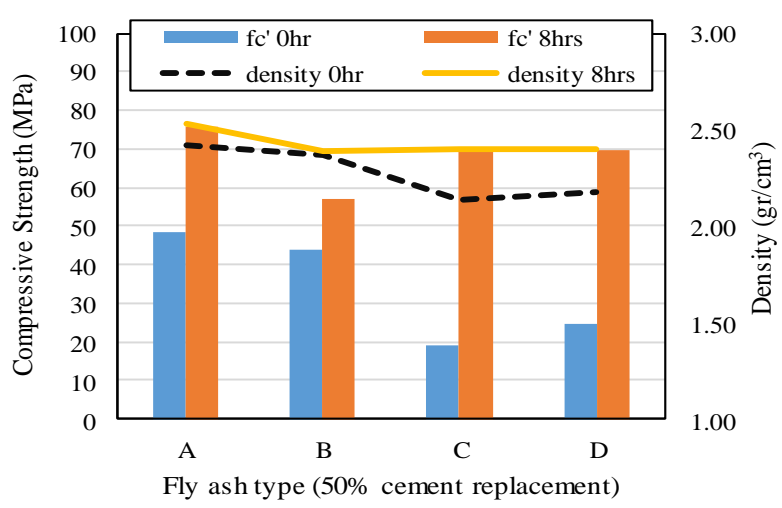

Figure 5. Compressive Strength and Density of HVFA Mortar with 50\% Replacement Ratio at 28 Days of Age

Milling fine fly ash A for eight hours only slightly affected the particle size of the fly ash. The biggest particle size, as can be seen from the value of D100, reduced from $142.53 \mu \mathrm{m}$ to $97.87 \mu \mathrm{m}$; while D90 shows only a marginal reduction from $39.78 \mu \mathrm{m}$ to $34.84 \mu \mathrm{m}$. Practically, SSA values remained constant. Apparently, milling equipment used is only efective to grind big fly ash particle, i.e. bigger than $40 \mu \mathrm{m}$, whereby its presence in fly ash A is only minor.

Although milling for eight hours only slightly change the particle size distribution of fly ash A, Figure 4 shows that there is a significant increase in compressive strength of HVFA mortar using fly ash A that has been mechanically activated by milling. The amount of fly ash used was varied from 40 to $60 \%$ of the total cementitious materials in mass. The measured density of the mortar increased slightly, showing that there could be improvement on the particle packing of the mortar incorporating finer particle size.

Different picture can be seen from Figure 5. HVFA mortar utilizing fine fly ash B gained approximately $20 \%$ increase in its strength after using the ground fly ash. However, for the ones using the coarse fly ash $\mathrm{C}$ and $\mathrm{D}$, the increase in compressive strength due to using the ground fly ash is very big. HVFA 
mortar utilizing ground fly ash C and D gained $264 \%$ and $183 \%$ strength increase, respectively, compared to those using the untreated fly ash.

The untreated coarse fly ash with high LOIs (i.e. fly ash $\mathrm{C}$ and $\mathrm{D}$ ) are not reactive, as can be seen from the low compressive strength of mortar utilizing them. Milling for eight hours significantly affected the particle size distribution of fly ash $\mathrm{C}$ and D. For fly ash C, eight hours milling reduced its D90 size from 152.89 to $43.33 \mu \mathrm{m}$, its D50 value from 46.76 to $9.01 \mu \mathrm{m}$, and increased the SSA value from 462 to $1506 \mathrm{~m}^{2} / \mathrm{kg}$. Very considerable increase also happened to the coarse fly ash D.

The results confirm that mechanical activation by milling effectively increase the reactivity of coarse fly ash with high LOIs. It also reveal that the simple grinding equipment used is very effective for the purpose.

Low specific gravity of untreated fly ash $\mathrm{C}$ and $\mathrm{D}$, i.e. 1.64 and 1.83 , respectively, taking more volume in the HVFA mortar, causing lower density for the mortar. Using ground fly ash C and D increased HVFA mortar density.

\section{LOI, Density, and Mechanical Activation}

Relationship between mortar density and its compressive strength is shown in Figure 6. It shows that there are significant improvement on the properties of HVFA mortar incorporating fly ash $\mathrm{C}$ and $\mathrm{D}$, compared to the ones using fly ash $\mathrm{A}$ and $\mathrm{B}$.

After milling, fly ash C and D with LOIs higher than $20 \%$ are eligible to be used as cement replacement material with $50 \%$ replacement ratio, to produce comparable compressive strength of HVFA mortar utilizing fly ash A and B. Mechanical activation by means of milling can be the best alternative in an attempt to utilize the undesired coarse fly ash with high LOI in concrete industry.

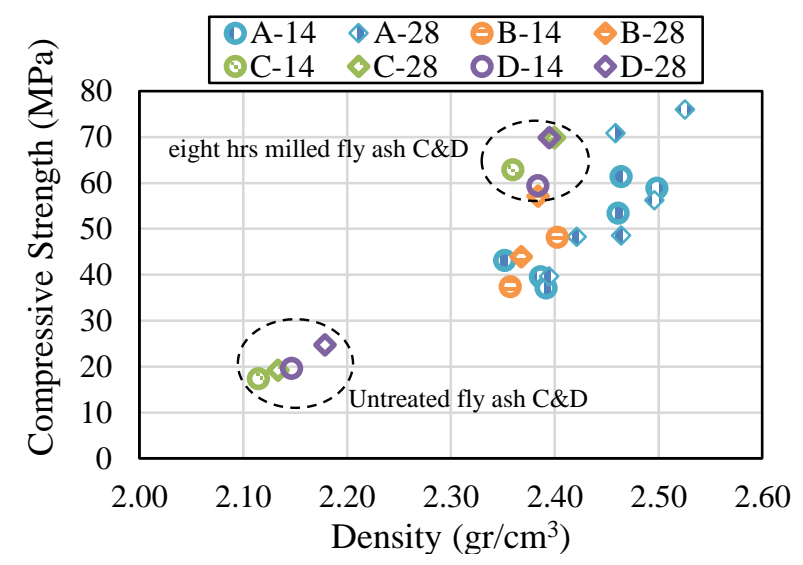

Figure 6. Relationship between the Density and Strength of HVFA Mortar at 14 and 28 days

\section{Conclusions}

1. Simple mechanical activation by using a rod mill improves the reactivity of fly ash significantly, especially the ones with coarse particle size and high LOI, due to change in the particle size distribution.

2. Compressive strength of the HVFA mortar utilizing milled fly ash is significatly higher than the ones utilizing the untreated one. The strength increase is very significant for HVFA mortar incorporating fly ash with high LOI and originally coarse particle size fly ash.

3. Change of the particle shape and size of fly ash affects the rheological behavior of the fresh HVFA mortar mixture. The superplasticizer demand increased when using the milled fly ash to obtain the same consistency.

\section{References}

1. Soong, Y., Schoffstall, M.R., Gray, M.L., Knoer, J.P., Champagne, K.J., Jones, R.J., and Fauth, D.J., Dry Beneficiation of High Loss-on-ignition Fly Ash, Separation and Purification Technology, 26(2-3), 2002, pp. 177-184.

2. Yao, Z.T., Ji, X.S., Sarker, P.K., Tang, J.H., Ge, L.Q., Xia, M.S., and Xi, Y.Q., A Comprehensive Review on the Applications of Coal Fly Ash, Earth-Science Reviews, 141(2), 2015, pp. 105121.

3. Salain, I.M.A.K., Study on Reactivity of Circulating Fluidized Bed Combustion Fly Ashes in the Presence of Water, Civil Engineering Dimension, 12(1), 2010, pp. 29-35.

4. Lee, S.J., Cho, H.C., and Kwon, J.H., Beneficiation of Coal Pond Ash by Physical Separation Techniques, Journal of Environmental Management, 104(8), 2012, pp. 77-84.

5. Blanco, F., Garcia, M.P., Ayala, J., Mayoral, G., and Garcia, M.A., The Effect of Mechanically and Chemically Activated Fly Ashes on Mortar Properties, Fuel, 2018-2026(14-15), 2006, pp. 2018-2026.

6. Cammarota, A., Chirone, R., Solimene, R., and Urciuolo, M., Beneficiation of Pulverized Coal Combustion Fly ash in Fluidised Bed Reactors, Experimental Thermal and Fluid Science, 32(7), 2008, pp. 1324-1333.

7. Soong, Y., Schoffstall, M.R., and Link, T.A., Triboelectrostatic Beneficiation of Fly Ash, Fuel, 80(6), 2001, pp. 879-884.

8. Kumar, R.S.K. and Mehrotra, S.P., Towards Sustainable Solutions for Fly Ash through Mechanical Activation, Resources, Conservation, and Recycling, 52(2), 2007, pp. 157-179.

9. Kumar, S. and Kumar, R., Mechanical Activation of Fly Ash: Effect on Reaction, Structure and Properties of Resulting Geopolymer, Ceramics International, 37(2), 2011, pp. 533-541. 
10. Senneca, O., Salatino, P., Chirone, R., Cortese, L., and Solimene, R., Mechanochemical Activation of High-carbon Fly Ash for Enhanced Carbon Reburning, Proceedings of the Combustion Institute, 33(2), 2011, pp. 2743-2753.

11. Temuujin, J., Williams, R.P., and van Riessen, A., Effect of Mechanical Activation of Fly Ash on the Properties of Geopolymer Cured at Ambient Temperature, Journal of Materials Processing Technology, 209(12-13), 2009, pp. 5276-5280.

12. van Riessen, A. and Tan, N.C., Beneficiation of Collie Fly Ash for Synthesis of Geopolymer: Part 1-Beneficiation, Fuel, 106(4), 2013, pp. 569-575.
13. Ahmaruzzaman, M., A Review on the Utilization of Fly Ash, Progress in Energy and Combustion Science, 36(3), 2010, pp. 327-363.

14. ASTM C618-12a, Standard Specification for Coal Fly Ash and Raw or Calcined Natural Pozzolan for Use in Concrete. ASTM International: West Conshohocken, PA, 2012.

15. Antoni, Wiyono, D., Vianthi, A., Putra, P., Kartadinata, G., and Hardjito, D., Effect of Particle Size on Properties of Sidoarjo Mudbased Geopolymer, Materials Science Forum, 803(2015), 2015, pp. 44-48. 